\title{
PENGARUH SIKAP KERJA, LINGKUNGAN KERJA DAN MOTIVASI KERJA TERHADAP KINERJA PEGAWAI DI DINAS PEKERJAAN UMUM DAN PENATAAN RUANG KABUPATEN LABUHANBATU SELATAN
}

\author{
${ }^{1}$ Sahrul Tarigan, ${ }^{2}$ Rasman, ${ }^{3}$ Oryza Kuspranataga, ${ }^{4}$ T. Muhammad Iqbal, ${ }^{5}$ Puti Andam Sari \\ $1,2,3,4,5$ Universitas Islam Sumatera Utara \\ ${ }^{1}$ sahrul.tarigan@gmail.com, ${ }^{2}$ rasman.mm@gmail.com, ${ }^{3}$ oryza.kuspranataga@gmail.com, ${ }^{4}$ mhd.iqbal@gmail.com, \\ ${ }^{5}$ putiandam.sari@gmail.com
}

\begin{abstract}
Problem of this study how influence of job attitude on performance. How influence of job environment on performance. How influence of job motivation on performance. How influence job attitude, job environment and job motivation on performance. The purpose of this study to determine and analyze the effect of job attitude on performance. Determine and analyze the effect of job environment on performance. Determine and analyze the effect of job motivation on performance. Determine and analyze the effect of job attitude, job environment and job motivation on performance. Sample in the study is 52 employees. Data analysis techniques used in this study is descriptive analyze and multiple linear regression analysis. The results of the study indicate job attitude variable has a positive and significant effect on performance. Job environment variable has a positive and significant effect on performance. Job motivation variable has a positive and significant effect on performance. Job attitude, job environment and job motivation variable has a positive and significant effect on performance.
\end{abstract}

Keywords : Job attitude, Job environment, Job motivation, Performance.

ABSTRAK : Rumusan masalah dalam penelitian ini adalah apakah ada pengaruh sikap kerja terhadap kinerja. Apakah ada pengaruh lingkungan kerja terhadap kinerja. Apakah ada pengaruh motivasi kerja terhadap kinerja. Apakah ada pengaruh sikap kerja, lingkungan kerja dan motivasi kerja terhadap kinerja. Tujuan penelitian ini adalah untuk mengetahui dan menganalisis pengaruh sikap kerja terhadap kinerja. Untuk mengetahui dan menganalisis pengaruh lingkungan kerja terhadap kinerja. Untuk mengetahui dan menganalisis pengaruh motivasi kerja terhadap kinerja. Untuk mengetahui dan menganalisis pengaruh sikap kerja, lingkungan kerja dan motivasi kerja terhadap kinerja. Sampel dalam penelitian ini berjumlah 52 orang pegawai. Teknik analisis data yang digunakan dalam penelitian ini adalah analisis deskriptif dan analisis regresi linier berganda. Hasil penelitian ini menjelaskan bahwa variabel sikap kerja berpengaruh positif dan signifikan terhadap kinerja. Variabel lingkungan kerja berpengaruh positif dan signifikan terhadap kinerja. Variabel motivasi kerja berpengaruh positif dan signifikan terhadap kinerja. Variabel sikap kerja, lingkungan kerja, dan motivasi kerja berpengaruh positif dan signifikan terhadap kinerja.

Kata kunci : Sikap kerja, Lingkungan kerja, Motivasi kerja, Kinerja

\section{Pendahuluan}

Dinas Pekerjaan Umum dan Penataan Ruang Kabupaten Labuhanbatu Selatan yang merupakan perpanjangan tangan dari pemerintah pusat yakni Kementrian Pekerjaan Umum dan Perumahan Rakyat, kehadirannya sangat memberikan warna terhadap pelayanan publik. Dinas Pekerjaan Umum Dan Penataan Ruang Kabupaten Labuhanbatu Selatan adalah perangkat daerah yang diserahkaan wewenang, tugas dan tanggung jawab untuk melaksanakan otonomi daerah dalam bidang pekerjaan umum dan penataan ruang. Untuk mewujudkan tujuan pekerjaan pemerintahan yang berkualitas manajemen sumber daya manusia harus benarbenar dikelola.

Menurut Hasibuan (2016:66), Manajemen Sumber Daya Manusia (MSDM) adalalah ilmu dan seni mengatur hubungan dan perananan tenaga kerja agar terwujudnya tujuan 
perusahaan, karyawan, dan masyarakat. Dalam hal ini sumber daya manusia sebagai pegawai. Pegawai yang bergerak di bidang jasa guna melayani masyarakat melalui pemeliharaan dan pembuatan jalan. Dinas Pekerjaan Umum Dan Penataan Ruang Kabupaten Labuhanbatu Selatan yang melaksanakan tugas sebagai penyusunan dan perumusan rencana program kegiatan dan prosedur tetap dalam rangka pelaksanaan kebijakan tehnis di bidang sarana dan prasarana di wilayah Kabupaten Labuhanbatu Selatan, juga sebagai pelaksana penataan, pemenuhan dan evaluasi kebutuhan sarana dan prasarana sesuai standar, prosedur dan norma yang ditetapkan oleh pemerintah daerah.

Untuk mencapai tujuan Dinas Pekerjaan Umum Dan Penataan Ruang Kabupaten Labuhanbatu Selatan tersebut diperlukan kinerja instansi yang baik, yang didasarkan pada kinerja pegawai. Kinerja merupakan suatu potensi yang harus dimiliki oleh setiap pegawai untuk melaksanakan setiap tugas dan tanggung jawab yang diberikan organisasi kepada pegawai. Dengan kinerja yang baik, maka setiap pegawai dapat menyelesaikan segala beban organisasi dengan efektif dan efisien sehingga masalah yang terjadi pada organisasi dapat teratasi dengan baik. Kinerja dapat diartikan penampilan hasil kerja pegawai baik secara kuantitas maupun kualitas.

Menurut Mangkunegara

pengertian kinerja adalah hasil kerja secara kualitas dan kuantitas yang dicapai oleh seorang pegawai dalam melaksanakan tugasnya sesuai dengan tanggung jawab yang diberikan kepadanya. Kinerja juga dapat dikatakan hasil dari suatu proses yang mengacu dan diukur selama periode tertentu berdasarkan ketentuan atau kesepakatan yang telah ditetapkan sebelumnya. Jadi, dapat disimpulkan bahwa kinerja merupakan keseluruhan aktfitas dalam melakukan tugasnya terhadap perusahaan atau instansi sesuai dengan tanggung jawabnya masing-masing individu terhadap instansi. Oleh karena itu, pegawai di instansi tersebut harus memiliki kualitas, keterampilan, dan memiliki kompetensi yang sesuai dengan pekerjaannya agar dapat melayani masyarakat dan juga dapat meningkatkan prestasi kerja yang berdampak baik bagi masyarakat maupun instansi itu sendiri.

Pemeliharaan infrastruktur jalan Kabupaten Labuhanbatu Selatan sampai sekarang ini belum dapat dikatakan baik, itu di karenakan kurangnya perhatian pemerintah daerah dalam pemeliharaan infrastruktur jalan yang dalam hal ini Dinas Pekerjaan Umum Dan Penataan Ruang Kabupaten Labuhanbatu Selatan sehingga di beberapa titik jalan di bebeberapa Kabupaten Labuhanbatu Selatan masih mengalami kerusakan seperti contoh munculnya lubang di sekitaran jalan dan bahkan sampai di tengah jalan. Dalam pemeliharaan jalan bukan hanya bagian jalanya yang harus di perhatikan akan tetapi beberapa bagian konstruksi jalan juga harus di perhatikan, seperti struktur perkerasan jalan, bahu jalan, trotoar, drainase jalan dan struktur lain pendukung jalan. Dalam pra observasi yang peneliti lakukan ada beberapa titik jalan yang dalam pemeliharaannya hanya mengutamakan jalan yang di lalui oleh kendaraan bermotor, sehingga menyebabkan kapasitas jalan tidak bertahan lama. Sehingga membuat masyarakat mengalami ketidaknyamanan saat menggunakan sarana dari pemerintah ini. Hal ini menyebabkan timbulnya pemikiranpemikiran kritis dari masyarakat yang menganggap bahwa pemerintah hanya menjadikan pembangunan infrastruktur jalan sebagai alasan agar supaya setiap dana yang dialokasikan untuk pembangunan dan perawatan infrastruktur jalan dapat disisipkan untuk kepentingan personal, sehingga dana yang seharusnya di gunakan untuk kepentingan daerah dan masyarakat tidak digunakan sebagai mana mestinya. Pada akhirnya menimbulkan keraguan bagi masyarakat karena pemerintah dianggap tidak bekerja sesuai dengan harapan masyarakat.

Berdasarkan pada fenomena tersebut, salah satu faktor yang mempengaruhi kinerja pegawai di Dinas Pekerjaan Umum Dan Penataan Ruang Kabupaten Labuhanbatu Selatan adalah motivasi kerja. Siagian (2014:77) menyatakan motivasi adalah daya pendorong yang mengakibatkan seseorang mau dan rela mengerahkan kemampuan dalam bentuk keahlian atau keterampilan, tenaga dan waktunya untuk menyelenggarakan berbagai kegiatan yang menjadi tanggung jawabnya dalam rangka pencapaian tujuan organisasi. Seorang yang memiliki motivasi yang rendah mereka cenderung untuk memperlihatkan upaya yang tidak maksimal dalam melaksanakan pekerjaannya, sehingga semakin tinggi motivasi yang dimiliki oleh individu sebagai pegawai maka dapat meningkatkan kinerja pegawai itu sendiri. Dengan demikian, Dinas Pekerjaan 
Umum Dan Penataan Ruang Kabupaten Labuhanbatu Selatan perlu mengetahui apa yang menjadi motivasi para pegawainya, sebab faktor tersebut dapat menjadi salah satu faktor yang menentukan tinggi atau rendahnya motivasi seorang pegawai dalam melaksanakan pekerjaan. Fakta yang ditemukan di Dinas Pekerjaan Umum Dan Penataan Ruang Kabupaten Labuhanbatu Selatan menunjukkan masih ada pegawai yang terlambat masuk kerja dan pulang sebelum jam kerja. Dari data rekapitusai absensi pegawai dapat dilihat bahwa rata-rata keterlambatan pegawai masuk kerja pada Tahun 2020 adalah $8 \%$ dan rata-rata pegawai yang pulang sebelum jam kerja adalah $11 \%$. Kondisi ini merefleksikan bahwa motivasi kerja pegawai di Dinas Pekerjaan Umum Dan Penataan Ruang Kabupaten Labuhanbatu Selatan masih perlu mendapat perhatian serius. Hubungan motivasi terhadap kinerja dalam penelitian ini didukung oleh beberapa penelitian terdahulu seperti Abdullah et.al. (2013), Ali et.al (2016), Milka et.al (2015), Noviansyah (2011) dan Saeed et.al (2016), kesemuanya menyatakan bahwa motivasi berpengaruh signifikan terhadap kinerja.

Faktor berikutnya yang mempengaruhi kinerja pegawai di Dinas Pekerjaan Umum Dan Penataan Ruang Kabupaten Labuhanbatu Selatan adalah lingkungan kerja. Dessler (2008:133), menyatakan lingkungan kerja merupakan segala situasi yang terbentuk di dalam organisasi sebagai hasil interaksi antara antara atasan dengan bawahan, dan antara pegawai dengan pegawai lainnya. Hubungan dalam lingkungan kerja ada empat karakter, yaitu personalisasi, partisipasi, ketertiban, dan kejelasan arah tugas serta tanggung jawab. Kelemahan yang terjadi di Dinas Pekerjaan Umum Dan Penataan Ruang Kabupaten Labuhanbatu Selatan diantaranya masih kurangnya sarana prasarana kerja pegawai dan fasilitas IT masih kurang. Hubungan linier antara lingkungan kerja dengan kinerja dalam penelitian ini didukung oleh penelitian terdahulu dari Wibawa (2014), dan Muzammil (2014), keduanya menyatakan lingkungan kerja berpengaruh signifikan terhadap kinerja.

Faktor yang tidak kalah penting, yang dapat mempengaruhi kinerja pegawai di Dinas Pekerjaan Umum Dan Penataan Ruang Kabupaten Labuhanbatu Selatan adalah sikap kerja. Karena sikap kerja merupakan tindakan yang akan diambil pegawai dan kewajiban yang harus dilaksanakan sesuai dengan tanggung jawab yang hasilnya sebanding dengan usaha yang dilakukan. Sikap kerja dapat dijadikan indikator dalam sebuah pekerjaan dapat berjalan lancar atau tidak, masalah antar pegawai ataupun atasan dapat mengakibatkan terabaikannya sikap kerja. Hubungan linier antara sikap kerja dengan kinerja dalam penelitian ini didukung oleh beberapa penelitian terdahulu dari Chres F.P Laoh et.al (2016), Famella et.al (2015), Fonny Corryda Rahayu (2013), dan Alias et.al (2018), kesemuanya menarik kesimpulan sikap kerja berpengaruh positif dan signifikan terhadap kinerja. Sementara hasil penelitian terdahulu dari $R d$. Kresna et.al (2017), menarik kesimpulan sikap kerja berpengaruh negati dan tidak terhadap kinerja. Tidak konsistennya dari penelitian terdahulu tersebut sehingga peneliti tertarik melakukan penelitian lanjutan terhadap pegawai di Dinas Pekerjaan Umum Dan Penataan Ruang Kabupaten Labuhanbatu Selatan.

\subsection{Rumusan Masalah}

Berdasarkan batasan masalah yang telah diidentifikasi maka peneliti merumuskan masalah yang berkaitan dengan penelitian ini adalah :

1) Apakah ada pengaruh sikap kerja terhadap kinerja pegawai di Dinas Pekerjaan Umum Dan Penataan Ruang Kabupaten Labuhanbatu Selatan.

2) Apakah ada pengaruh lingkungan kerja terhadap kinerja pegawai di Dinas Pekerjaan Umum Dan Penataan Ruang Kabupaten Labuhanbatu Selatan.

3) Apakah ada pengaruh motivasi kerja terhadap kinerja pegawai di Dinas Pekerjaan Umum Dan Penataan Ruang Kabupaten Labuhanbatu Selatan.

4) Apakah ada pengaruh sikap kerja, lingkungan kerja, dan motivasi kerja terhadap kinerja pegawai di Dinas Pekerjaan Umum Dan Penataan Ruang Kabupaten Labuhanbatu Selatan.

\subsection{Batasan Masalah}

Berdasarkan uraian di atas, banyak faktor yang berpengaruh pada variabel kinerja pegawai, sehingga dalam penelitian ini peneliti membatasi kepada variabel independen yaitu sikap kerja, lingkungan kerja dan motivasi kerja. 


\subsection{Hipotesis}

Hipotesis adalah jawaban sementara terhadap masalah penelitian, yang kebenarannya harus diuji secara empiris. Hipotesis dalam penelitian ini adalah :

1) Sikap kerja berpengaruh positif dan signifikan terhadap kinerja pegawai di Dinas Pekerjaan Umum dan Penataan Ruang Daerah Kabupaten Labuhanbatu Selatan.

2) Lingkungan kerja berpengaruh positif dan signifikan terhadap kinerja pegawai di Dinas Pekerjaan Umum dan Penataan Ruang Daerah Kabupaten Labuhanbatu Selatan.

3) Motivasi kerja berpengaruh positif dan signifikan terhadap kinerja pegawai di Dinas Pekerjaan Umum dan Penataan Ruang Daerah Kabupaten Labuhanbatu Selatan.

4) Sikap kerja, lingkungan kerja dan motivasi kerja berpengaruh positif dan signifikan terhadap kinerja pegawai di Dinas Pekerjaan Umum dan Penataan Ruang Daerah Kabupaten Labuhanbatu Selatan.

\subsection{Tujuan Penelitian}

Tujuan dari penelitian ini adalah :

1) Untuk menganalisis pengaruh sikap kerja terhadap kinerja pegawai di Dinas Pekerjaan Umum Dan Penataan Ruang Kabupaten Labuhanbatu Selatan.

Tabel 1. Kerangka populasi berdasarkan bagian

\begin{tabular}{|c|l|c|}
\hline No & \multicolumn{1}{|c|}{ Status } & Jumlah \\
\hline 1. & Sekretariat & 7 \\
\hline 2. & Bidang Cipta Karya & 10 \\
\hline 3. & Bidang Bina Marga & 10 \\
\hline 4. & Bidang Sumber Daya Air dan Drainase & 8 \\
\hline 5. & Bidang Penataan Ruang & 8 \\
\hline 6. & Bidang Pertamanan dan Penerangan & 52 \\
\hline \multicolumn{2}{|c|}{ Jumlah } & Sumber :Dinas Pekerjaan Umum dan Penataan Ruang Daerah Kabupaten Labuhanbatu Selatan, 2021
\end{tabular}

\subsection{Sampel}

Menurut Sugiyono (2014:93), sampel adalah elemen-elemen populasi yang dipilih atas dasar kemampuan mewakilinya. Untuk menjadi pedoman jika subjeknya atau populasinya kurang dari 100, maka lebih baik diambil semua sebagai sampel, sehingga penelitiannya merupakan penelitian populasi. Selanjutnya jika jumlah subjeknya atau populasinya besar atau lebih dari 100, maka dapat diambil persentasenya. Dengan teknik penarikan sampel secara total sampling, maka sampel dalam penelitian ini berjumlah 52 orang pegawai Dinas Pekerjaan Umum dan Penataan Ruang Daerah Kabupaten Labuhanbatu Selatan.
2) Untuk menganalisis pengaruh lingkungan kerja terhadap kinerja pegawai di Dinas Pekerjaan Umum Dan Penataan Ruang Kabupaten Labuhanbatu Selatan.

3) Untuk menganalisis pengaruh motivasi kerja terhadap kinerja pegawai di Dinas Pekerjaan Umum Dan Penataan Ruang Kabupaten Labuhanbatu Selatan.

4) Untuk menganalisis pengaruh sikap kerja, lingkungan kerja, dan motivasi kerja terhadap kinerja pegawai di Dinas Pekerjaan Umum Dan Penataan Ruang Kabupaten Labuhanbatu Selatan.

\section{Metode Penelitian \\ 2.1. Populasi}

Menurut Sugiyono (2014:90), populasi adalah wilayah generasi yang terdiri dari atas objek/subjek yang mempunyai kualitas dan karakteristik tertentu yang disajikan oleh peneliti untuk dipelajari dan kemudian ditarik kesimpulannya. Berdasarkan defenisi tersebut, maka populasi dalam penelitian ini adalah para pegawai Dinas Pekerjaan Umum dan Penataan Ruang Daerah Kabupaten Labuhanbatu Selatan yang berjumlah 52 orang, dimana peneliti tidak dihitung sebagai populasi. 
lurus diagonal dan ploating data residual akan dibandingkan dengan garis diagonal. Jika distribusi atau residual normal, maka garis yang menggambarkan data yang sesungguhnya akan mengikuti garis diagonalnya. Uji normalitas dengan grafik dapat dilakukan dengan program SPSS dengan analisis grafik Normal Probability Plot

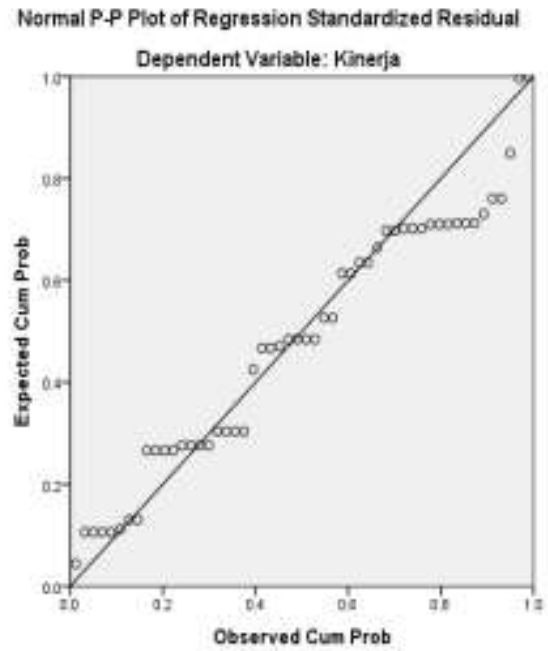

Gambar 1. Uji normalitas data

Berdasarkan gambar 1, diatas terlihat titiktitik dari ploating data residual berada di garis diagonal, hal ini dapat disimpulkan data yang diuji berdistribusi normal.

\subsection{Uji Multikolinieritas}

Salah satu asumsi dari model regresi linier bahwa tidak terjadi korelasi yang signifikan antara variabel bebasnya. Untuk menguji hal tersebut maka diperlukan suatu uji yang disebut uji multikolinieritas. Menurut Sugiyono (2014:151) pengertian multikolinieritas adalah keadaan di mana pada model regresi ditemukan adanya korelasi yang sempurna atau mendekati sempurna antar variabel independen. Pada regresi yang baik seharusnya tidak terjadi korelasi yang sempurna atau mendekati sempurna diantara variabel bebas. Uji multikolinieritas adalah untuk melihat ada atau tidaknya korelasi yang tinggi antara variabelvariabel bebasnya, maka hubungan antara variabel bebas terhadap variabel terikatnya menjadi terganggu. Jika terdapat korelasi yang kuat dimana sesama variabel independen maka konsekuensinya adalah :

a. Koefisien-koefisien regresi menjadi tidak dapat ditaksir b. Nilai standar error setiap koefisien regresi menjadi tidak terhingga.

Dengan demikian, semakin besar korelasi diantara sesama variabel independen maka tingkat kesalahan dari koefisien regresi semakin besar yang dapat mengakibatkan standar error semakin besar pula. Cara yang digunakan untuk mendeteksi ada tidaknya multikolinieritas adalah dengan melihat besarnya nilai Variance Inflation Factor (VIF). Jika VIF dibawah 10 dan Tolerance Value diatas 0,1 maka tidak terjadi multikolinieritas.

Tabel 3. Uji multikolinieritas

\begin{tabular}{|l|c|c|}
\hline \multirow{2}{*}{ Variabel } & \multicolumn{2}{|c|}{ Collinearity Statistics } \\
\cline { 2 - 3 } & Tolerance & VIF \\
\hline Sikap kerja & 0.925 & 1.081 \\
\hline Lingkungan kerja & 0.705 & 1.419 \\
\hline Motivasi kerja & 0.722 & 1.385 \\
\hline \multicolumn{2}{|c|}{$\begin{array}{c}\text { a Dependent Variable : Kinerja } \\
\text { Sumber : Hasil pengolahan data, 2021 }\end{array}$}
\end{tabular}

Berdasarkan Tabel 3 diatas diperoleh nilai Tolerance Value diatas 0.1 yaitu $0.925,0.705$, 0.722; hal ini menunjukan adanya korelasi yang cukup tinggi/kuat antara sesama variabel bebas dan nilai Variance Inflantion Factorrs (VIF) sebesar 1.081, 1.419, 1.385, dimana nilai VIF dari ketiga varibel bebas lebih kecil dari 10 dan dapat disimpulkan tidak terdapat multikolinieritas diantara ketiga variabel bebas yang diuji dalam penelitian ini.

\subsection{Uji Autokorelasi}

Uji autokorelasi merupakan pengujian dimana variabel dependen tidak berkorelasi dengan nilai variabel itu sendiri, baik nilai periode sebelumnya maupun nilai periode sesudahnya. Menurut Sugiyono (2014:172) pengertian dari autokorelasi adalah keadaan di mana pada model regresi ada korelasi antara residual pada periode tertentu $t$ dengan residual pada periode sebelumnya ( $\mathrm{t}-1)$, model regresi yang baik adalah yang tidak terdapat masalah autokorelasi. Metode pengujian menggunakan uji Durbin-Watson (DW-test). Salah satu ukuran dalam menentukan ada tidaknya masalah autokorelasi dengan uji Durbin-Watson (DW) dengan ketentuan sebagai berikut :

$1.65<\mathrm{DW}<2.35$ tidak terjadi autokorelasi

1.21. $<\mathrm{DW}<1.65$ atau $2.35<\mathrm{DW}<2.79$ tidak dapat disimpulkan.

$\mathrm{DW}<1.21$ atau DW $>2.79$ terjadi autokorelasi. 
Tabel 4. Uji Autokorelasi

\begin{tabular}{|l|r|r|r|r|r|r|}
\hline \multirow{4}{*}{ Model } & \multicolumn{7}{|c|}{ Change Statistics } & \multirow{2}{*}{$\begin{array}{c}\text { Durbin- } \\
\text { Watson }\end{array}$} \\
\cline { 2 - 7 } & $\begin{array}{c}\text { R Square } \\
\text { Change }\end{array}$ & F Change & df1 & df2 & $\begin{array}{c}\text { Sig. F } \\
\text { Change }\end{array}$ & \\
\hline 1 & .711 & 39.420 & 3 & 48 & .000 & 2.090 \\
\hline
\end{tabular}

Berdasarkan Tabel 4 di atas diperoleh nilai Durbin-Watson (DW) sebesar 2.090, nilai ini berada pada kisaran $1.65<\mathrm{DW}<2.35$, maka dapat disimpulkan bahwa tidak terjadi autokorelasi pada model regresi yang diuji dalam penelitian ini.

\subsection{Uji Heteroskedastisitas}

Uji heteroskedastisitas bertujuan untuk menguji apakah dalam model regresi terjadi ketidaksamaan variance dari residual satu pengamatan ke pengamatan yang lainnya. Gejala variance yang tidak sama ini disebut dengan heteroskedastisitas, sedangkan adanya gejala residual yang sama dari satu pengamatan ke pengamatan lain disebut dengan homokedastisitas. Menurut Sugiyono (2014:158) pengertian dari heteroskedastisitas adalah dimana dalam model regresi tejadi ketidaksamaan varian dari residual pada suatu pengamatan ke pengamatan yang lain. Model regresi yang baik adalah tidak terjadi heteroskedastisitas. Berbagai macam uji heteroskedastisitas yaitu dengan uji glejser, melihat pola titik-titik pada scatterplots regresi, atau uji koefisien korelasi spearman's.

Uji heteroskedastisitas dapat dilakukan dengan menggunakan grafik scatterplot antara nilai variabel terikat (ZSPRED) dengan residualnya (SRESID), dimana sumbu $X$ adalah yang diprediksi dan sumbu $\mathrm{Y}$ adalah residual. Dasar pengambilan keputusan yang dapat diambil adalah sebagai berikut :

a. Jika pola tertentu seperti titik-titik yang ada membentuk suatu pola yang teratur (bergelombang, melebar kemudian menyempit) maka telah terjadi heteroskedastisitas.

b. Jika tidak ada yang jelas serta titik-titik menyebar diatas dan dibawah angka nol pada sumbu $\mathrm{Y}$ maka tidak terjadi heteroskedastisitas

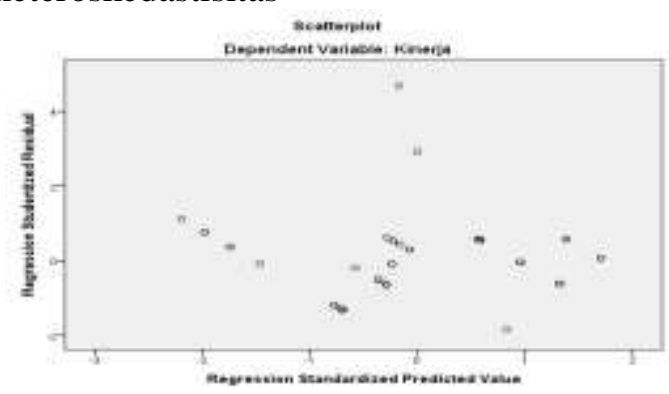

Gambar 2. Uji heteroskedastisitas

Berdasarkan gambar 2, diatas, menunjukkan titik-titik yang menyebar, sehingga dapat disimpulkan tidak terjadi heteroskedastisitas di data penelitian ini.

\section{Evaluasi Data}

Dalam evaluasi data ini peneliti akan melihat model persamaan regresi linier berganda dan akan menguji kebenaran hipotesis baik itu secara partial atau sendiri-sendiri, maupun secara simultan atau bersama-sama.

\subsection{Analisis Regresi Linier Berganda.}

Analisis regresi linier berganda dalam penelitian ini dapat dilihat dari persamaan regresinya, dan dari hasil pengolahan data diperoleh hasil berikut ini :

Tabel 5. Analisis regresi linier berganda

\begin{tabular}{|l|r|r|r|r|c|}
\hline \multirow{2}{*}{ Model } & \multicolumn{2}{|c|}{$\begin{array}{c}\text { Unstandardized } \\
\text { Coefficients }\end{array}$} & $\begin{array}{c}\text { Standardized } \\
\text { Coefficients } \\
\text { Beta }\end{array}$ & \multirow{2}{*}{$\mathrm{t}$} & \multirow{2}{*}{ Sig. } \\
\cline { 2 - 3 } & \multicolumn{1}{|c|}{$\mathrm{B}$} & Std. Error & & \\
\hline (Constant) & 2.971 & 3.800 & & .782 & .438 \\
\hline Sikap kerja & .149 & .057 & .209 & 2.597 & .012 \\
\hline Lingkungan kerja & .523 & .093 & .522 & 5.650 & .000 \\
\hline Motivasi kerja & .258 & .068 & .346 & 3.785 & .000 \\
\hline
\end{tabular}

Sumber : Hasil pengolahan data, 2021 
Berdasarkan Tabel 5, diatas dapat dibuat persamaan regresi dalam penelitian ini sebagai berikut:

$$
\mathrm{Y}=2.971+0.149 \mathrm{X}_{1}+0.523 \mathrm{X}_{2}+0.258 \mathrm{X}_{3}
$$

Dari persamaan regresi linier berganda di atas dapat dijelaskan :

1) Nilai kinerja pegawai di Dinas Pekerjaan Umum dan Penataan Ruang Kabupaten Labuhanbatu Selatan sebesar 2.971, dengan ketentuan nilai dari variabel bebas $\left(\mathrm{X}_{1}, \mathrm{X}_{2}\right.$, dan $\mathrm{X}_{3}$ ) diabaikan.

2) Nilai koefisien regresi $X_{1}$ (sikap kerja) mempunyai nilai positif yaitu 0.149 , hal ini menunjukkan bahwa variabel sikap kerja mempunyai pengaruh positif terhadap kinerja pegawai di Dinas Pekerjaan Umum dan Penataan Ruang Kabupaten Labuhanbatu Selatan.

3) Nilai koefisien regresi $X_{2}$ (lingkungan kerja) mempunyai nilai positif yaitu 0.523 , hal ini menunjukkan bahwa variabel lingkungan kerja mempunyai pengaruh positif terhadap kinerja pegawai di Dinas Pekerjaan Umum dan Penataan Ruang Kabupaten Labuhanbatu Selatan.

4) Nilai koefisien regresi $X_{3}$ (motivasi kerja) mempunyai nilai positif yaitu 0.258 , hal ini menunjukkan bahwa variabel motivasi kerja mempunyai pengaruh positif terhadap kinerja pegawai di Dinas Pekerjaan Umum dan Penataan Ruang Kabupaten Labuhanbatu Selatan.

\subsection{Pengaruh Sikap Kerja Terhadap Kinerja Pegawai Di Dinas Pekerjaan Umum dan Penataan Ruang Kabupaten Labuhanbatu Selatan.}

Untuk mengetahui pengaruh sikap kerja terhadap kinerja pegawai di Dinas Pekerjaan Umum dan Penataan Ruang Kabupaten Labuhanbatu Selatan. digunakan uji-t, sedangkan untuk melihat besarnya pengaruh digunakan nilai Beta atau Standardized Coefficient Beta.

Tabel 6. Pengaruh sikap kerja terhadap kinerja

\begin{tabular}{|l|r|r|r|r|r|}
\hline \multirow{2}{*}{ Model } & \multicolumn{2}{|c|}{$\begin{array}{c}\text { Unstandardized } \\
\text { Coefficients }\end{array}$} & $\begin{array}{c}\text { Standardized } \\
\text { Coefficients } \\
\text { Beta }\end{array}$ & \multirow{2}{*}{$\mathrm{t}$} & \multirow{2}{*}{ Sig. } \\
\cline { 2 - 3 } & \multicolumn{1}{|c|}{$\mathrm{B}$} & \multicolumn{1}{|c|}{ Std. Error } & & \\
\hline (Constant) & 2.971 & 3.800 & & .782 & .438 \\
\hline Sikap kerja & .149 & .057 & .209 & 2.597 & .012 \\
\hline
\end{tabular}

a. Dependent Variable : Kinerja

Sumber : Hasil pengolahan data, 2021

Dari Tabel 6 diatas diperoleh nilai $\mathrm{t}_{\text {hitung }}$ sebesar 2.597. Penelitian ini menggunakan taraf signifikansi $(\alpha: 0.05)$ dan Derajat Kebebasan (DK) dengan ketentuan DK $=\mathrm{n}-2$, atau $52-2$ $=50$. Dengan ketentuan tersebut, diperoleh nilai $\mathrm{t}_{\text {tabel }}$ sebesar 2.009. Dengan kriteria hipotesis sebagai berikut :

Jika nilai $t_{\text {hitung }}>t_{\text {tabel}}$, maka hipotesis penelitian diterima.

Jika nilai $t_{\text {hitung }}<t_{\text {tabel}}$, maka hipotesis penelitian ditolak.

Dari hasil pengolahan data diperoleh nilai $t_{\text {hitung }}>t_{\text {tabel }}(2.597>2.009)$ dan nilai signifikasi lebih kecil dari nilai $\alpha: 0.05$ yaitu $0.012<0.05$, sehingga hipotesis yang diajukan dalam penelitian ini diterima. Artinya variabel sikap kerja secara partial berpengaruh positif dan signifikan terhadap kinerja pegawai di Dinas Pekerjaan Umum dan Penataan Ruang Kabupaten Labuhanbatu Selatan. Besarnya pengaruh variabel sikap kerja terhadap kinerja pegawai di Dinas Pekerjaan Umum dan Penataan Ruang Kabupaten Labuhanbatu Selatan sebesar 0.209 atau 20.90\%. Hasil penelitian ini sejalan dengan hasil penelitian Agus Marimin (2011); Noviansyah dan Zunaidah (2011); Saeed, S., dan Syah, F.M (2016); Yazid, Musnadi dan Chan, (2013) yang mana kesemuanya menyatakan sikap kerja berpengaruh positif dan signifikan terhadap kinerja. Deskripsi dari hasil penelitian ini adalah jika tingkat sikap kerja sudah baik maka akan berdampak pada peningkatan kinerja pegawai, begitu juga sebalikny jika sikap kerja pegawai belum baik, maka akan berdampak pada penurunan kinerja pegawai di Dinas Pekerjaan Umum dan Penataan Ruang Kabupaten Labuhanbatu Selatan.

\subsection{Pengaruh Lingkungan Kerja Terhadap Kinerja Pegawai Di Dinas Pekerjaan}


Umum dan Penataan Ruang Kabupaten Labuhanbatu Selatan.

Untuk mengetahui pengaruh lingkungan kerja terhadap kinerja pegawai di Dinas Pekerjaan Umum dan Penataan Ruang
Kabupaten Labuhanbatu Selatan digunakan uji$\mathrm{t}$, sedangkan untuk melihat besarnya pengaruh digunakan nilai Beta atau Standardized Coefficient Beta.

Tabel 7 Pengaruh lingkungan kerja terhadap kinerja

\begin{tabular}{|l|r|r|r|r|r|}
\hline \multirow{2}{*}{ Model } & \multicolumn{2}{|c|}{$\begin{array}{c}\text { Unstandardized } \\
\text { Coefficients }\end{array}$} & $\begin{array}{c}\text { Standardized } \\
\text { Coefficients } \\
\text { Beta }\end{array}$ & \multirow{2}{*}{$\mathrm{t}$} & \multirow{2}{*}{ Sig. } \\
\cline { 2 - 3 } & \multicolumn{1}{|c|}{$\mathrm{B}$} & \multicolumn{1}{|c|}{ Std. Error } & & \\
\hline (Constant) & 2.971 & 3.800 & & .782 & .438 \\
\hline Lingkungan kerja & .523 & .093 & .522 & 5.650 & .000 \\
\hline
\end{tabular}

a. Dependent Variable : Kinerja

Sumber : Hasil pengolahan data, 2021

Dari Tabel 7 diatas diperoleh nilai $\mathrm{t}_{\text {hitung }}$ sebesar 5.650. Penelitian ini menggunakan taraf signifikansi $(\alpha: 0.05)$ dan Derajat Kebebasan (DK) dengan ketentuan DK $=\mathrm{n}-2$, atau $52-2$ $=50$. Dengan ketentuan tersebut, diperoleh nilai $\mathrm{t}_{\text {tabel }}$ sebesar 2.009. Dengan kriteria hipotesis sebagai berikut :

Jika nilai $t_{\text {hitung }}>t_{\text {tabel}}$, maka hipotesis penelitian diterima.

Jika nilai $\mathrm{t}_{\text {hitung }}<\mathrm{t}_{\text {tabel}}$, maka hipotesis penelitian ditolak.

Dari hasil pengolahan data diperoleh nilai $t_{\text {hitung }}>t_{\text {tabel }}(5.650>2.009)$ dan nilai signifikasi lebih kecil dari nilai $\alpha: 0.05$ yaitu $0.000<0.05$, sehingga hipotesis yang diajukan dalam penelitian ini diterima. Artinya variabel lingkungan kerja secara partial berpengaruh positif dan signifikan terhadap kinerja pegawai di Dinas Pekerjaan Umum dan Penataan Ruang Kabupaten Labuhanbatu Selatan. Besarnya pengaruh variabel lingkungan kerja terhadap kinerja pegawai di Dinas Pekerjaan Umum dan Penataan Ruang Kabupaten Labuhanbatu Selatan sebesar 0.522 atau $52.20 \%$. Hasil penelitian ini sejalan dengan hasil penelitian
Abubakr et.al, (2013); Dedi Hadian (2018); Muhd. Darwis Damir (2016); dan Nuraini Latief (2017), yang mana kesemuanya menyatakan lingkungan kerja berpengaruh positif dan signifikan terhadap kinerja. Deskripsi dari hasil penelitian ini adalah jika lingkungan kerja pegawai sudah baik maka akan berdampak pada peningkatan kinerja pegawai, begitu juga sebaliknya jika lingkungan kerja pegawai belum baik, maka akan berdampak pada penurunan kinerja pegawai di Dinas Pekerjaan Umum dan Penataan Ruang Kabupaten Labuhanbatu Selatan.

\subsection{Pengaruh Motivasi Kerja Terhadap Kinerja Pegawai Di Dinas Pekerjaan Umum dan Penataan Ruang Kabupaten Labuhanbatu Selatan.}

Untuk mengetahui pengaruh motivasi kerja terhadap kinerja pegawai di Dinas Pekerjaan Umum dan Penataan Ruang Kabupaten Labuhanbatu Selatan digunakan uji-t, sedangkan untuk melihat besarnya pengaruh digunakan nilai Beta atau Standardized Coefficient Beta.

Tabel 8 Pengaruh motivasi kerja terhadap kinerja

\begin{tabular}{|l|r|r|r|r|r|}
\hline \multirow{2}{*}{ Model } & \multicolumn{2}{|c|}{$\begin{array}{c}\text { Unstandardized } \\
\text { Coefficients }\end{array}$} & $\begin{array}{c}\text { Standardized } \\
\text { Coefficients } \\
\text { Beta }\end{array}$ & $\mathrm{t}$ & \multirow{2}{*}{ Sig. } \\
\cline { 2 - 3 } & \multicolumn{1}{|c|}{$\mathrm{B}$} & \multicolumn{1}{|c|}{ Std. Error } & & \\
\hline (Constant) & 2.971 & 3.800 & & .782 & .438 \\
\hline Motivasi kerja & .258 & .068 & .346 & 3.785 & .000 \\
\hline
\end{tabular}

a. Dependent Variable : Kinerja

Sumber : Hasil pengolahan data, 2021

Dari Tabel 8 diatas diperoleh nilai $\mathrm{t}_{\text {hitung }}$ sebesar 3.785. Penelitian ini menggunakan taraf signifikansi $(\alpha: 0.05)$ dan Derajat Kebebasan (DK) dengan ketentuan DK $=\mathrm{n}-2$, atau $52-2$ $=50$. Dengan ketentuan tersebut, diperoleh nilai $t_{\text {tabel }}$ sebesar 2.009. Dengan kriteria hipotesis sebagai berikut :

Jika nilai $t_{\text {hitung }}>t_{\text {tabel, }}$ maka hipotesis penelitian diterima. 
Jika nilai $t_{\text {hitung }}<\mathrm{t}_{\text {tabel }}$, maka hipotesis penelitian ditolak.

Dari hasil pengolahan data diperoleh nilai $t_{\text {hitung }}>t_{\text {tabel }}(3.785>2.009)$ dan nilai signifikasi lebih kecil dari nilai $\alpha: 0.05$ yaitu $0.000<0.05$, sehingga hipotesis yang diajukan dalam penelitian ini diterima. Artinya variabel motivasi kerja secara partial berpengaruh positif dan signifikan terhadap kinerja pegawai di Dinas Pekerjaan Umum dan Penataan Ruang Kabupaten Labuhanbatu Selatan. Besarnya pengaruh variabel motivasi kerja terhadap kinerja pegawai di Dinas Pekerjaan Umum dan Penataan Ruang Kabupaten Labuhanbatu Selatan sebesar 0.346 atau $34.60 \%$. Hasil penelitian ini sejalan dengan hasil penelitian Dedi Hadian (2018); Flavia et.al (2017); Muhd. Darwis Damir (2016); Regina Aditya Reza (2010); dan Sarwani (2017), yang mana kesemuanya menyatakan motivasi kerja berpengaruh positif dan signifikan terhadap kinerja. Deskripsi dari hasil penelitian ini adalah jika sistem atau program atau sistem motivasi kerja pegawai sudah berjalan dengan baik maka akan berdampak pada peningkatan kinerja pegawai, begitu juga sebaliknya jika sistem atau program atau sistem motivasi kerja pegawai belum berjalan dengan baik, maka akan berdampak pada penurunan kinerja pegawai di Dinas Pekerjaan Umum dan Penataan Ruang Kabupaten Labuhanbatu Selatan.

\subsection{Pengaruh Sikap Kerja, Lingkungan Kerja dan Motivasi Kerja Terhadap Kinerja Pegawai Di Dinas Pekerjaan Umum dan Penataan Ruang Kabupaten Labuhanbatu Selatan.}

Untuk mengetahui pengaruh sikap kerja, lingkungan kerja dan motivasi kerja terhadap kinerja pegawai di Dinas Pekerjaan Umum dan Penataan Ruang Kabupaten Labuhanbatu Selatan digunakan uji-F.

Tabel 9. Pengaruh sikap kerja, lingkungan kerja dan motivasi kerja terhadap kinerja

\begin{tabular}{|l|l|r|r|r|r|c|}
\hline \multirow{3}{*}{ Model } & & $\begin{array}{c}\text { Sum of } \\
\text { Squares }\end{array}$ & \multicolumn{1}{c|}{$\mathrm{df}$} & $\begin{array}{c}\text { Mean } \\
\text { Square }\end{array}$ & \multicolumn{1}{c|}{$\mathrm{F}$} & \multicolumn{1}{c|}{ Sig. } \\
\hline \multirow{1}{*}{1} & Regression & 306.335 & 3 & 102.112 & 39.420 & $.000^{\mathrm{b}}$ \\
\cline { 2 - 7 } & Residual & 124.338 & 48 & 2.590 & & \\
\cline { 2 - 7 } & Total & 430.673 & 51 & & & \\
\hline
\end{tabular}

Dependent Variable : Kinerja

Sumber : Hasil pengolahan data, 2021

Dari Tabel 9 di atas diperoleh nilai $\mathrm{F}_{\text {hitung }}$ sebesar 39.420. Penelitian ini menggunakan taraf signifikansi $(\alpha: 0.05)$ dan Derajat Kebebasan (DK) dengan ketentuan numerator : jumlah variabel -1 atau $4-1=3$, dan jumlah sampel dikurang 4 atau $52-4=48$. Dengan ketentuan tersebut, diperoleh nilai $\mathrm{F}_{\text {tabel }}$ sebesar 2.80. Dengan kriteria pengujian hipotesis sebagai berikut :

Jika $F_{\text {hitung }}>F_{\text {tabel }}$, maka hipotesis penelitian diterima.

Jika $F_{\text {hitung }}<\mathrm{F}_{\text {tabel }}$, maka hipotesis penelitian ditolak.

Dari hasil perhitungan diperoleh nilai $\mathrm{F}_{\text {hitung }}$ $>\mathrm{F}_{\text {tabel }}(39.420>2.80)$ dan nilai signifikasi 0.00 $<0.05$, sehingga hipotesis yang diajukan dalam penelitian ini diterima. Artinya variabel sikap kerja, lingkungan kerja dan motivasi kerja secara simultan berpengaruh positif dan signifikan terhadap kinerja pegawai di Dinas Pekerjaan Umum dan Penataan Ruang Kabupaten Labuhanbatu Selatan. Dengan demikian model regresi ini sudah layak dan benar dan dapat disimpulkan bahwa variabel sikap kerja, lingkungan kerja dan motivasi kerja berpengaruh terhadap kinerja pegawai di Dinas Pekerjaan Umum dan Penataan Ruang Kabupaten Labuhanbatu Selatan.

\subsection{Uji Determinan}

Uji determinan adalah untuk mengetahui seberapa besar pengaruh variabel sikap kerja, lingkungan kerja dan motivasi kerja terhadap kinerja pegawai di Dinas Pekerjaan Umum dan Penataan Ruang Kabupaten Labuhanbatu Selatan, dan dapat dilihat dari model summary, khususnya nilai Adjusted Rsquare. 
Tabel 10. Model summary ${ }^{\mathrm{b}}$ pengaruh sikap kerja, lingkungan kerja dan motivasi kerja terhadap kinerja

\begin{tabular}{|l|l|r|r|r|}
\hline Model & $R$ & $R$ Square & $\begin{array}{c}\text { Adjusted } R \\
\text { Square }\end{array}$ & $\begin{array}{c}\text { Std. Error of the } \\
\text { Estimate }\end{array}$ \\
\hline 1 & $.843^{\mathrm{a}}$ & .711 & .693 & 1.60946 \\
\hline
\end{tabular}

Dependent Variable : Kinerja

Sumber : Hasil pengolahan data, 2021

Besarnya Tabel 10 diatas diperoleh nilai Adjusted Rsquare $\left(\mathrm{r}^{2}\right)$ sebesar 0.711. Nilai tersebut mempunyai maksud bahwa pengaruh variabel sikap kerja, lingkungan kerja dan motivasi kerja terhadap kinerja pegawai di Dinas Pekerjaan Umum dan Penataan Ruang Kabupaten Labuhanbatu Selatan sebesar $71.10 \%$, sedangkan sisanya sebesar $28.90 \%$ dipengaruhi oleh faktor-faktor lain yang tidak diteliti. Dengan kata lain variabel kinerja pegawai di Dinas Pekerjaan Umum dan Penataan Ruang Kabupaten Labuhanbatu Selatan dapat diterangkan oleh variabel sikap kerja, lingkungan kerja dan motivasi kerja sebesar $71.10 \%$, sedangkan sisanya sebesar $28.90 \%$ disebabkan oleh variabel-variabel lain yang tidak diteliti.

\section{Pembahasan}

\subsection{Pengaruh Sikap Kerja Terhadap Kinerja Pegawai di Dinas Pekerjaan Umum dan Penataan Ruang Labuhanbatu Selatan.}

Berdasarkan pada hasil penelitian dapat dijelaskan bahwa sikap kerja berpengaruh positif dan signifikan terhadap kinerja pegawai di Dinas Pekerjaan Umum dan Penataan Ruang Kabupaten Labuhanbatu Selatan, hal ini didukung dengan hasil uji hipotesis yang menunjukkan bahwa nilai $t_{\text {hitung }}>t_{\text {tabel }}(2.597>$ 2.009) dan nilai signifikasi lebih kecil dari nilai $\alpha: 0.05$ yaitu $0.012<0.05$. Hasil penelitian ini sejalan dengan hasil penelitian terdahulu dari Chres F.P Laoh et.al (2016), Famella et.al (2015), Fonny Corryda Rahayu (2013), dan Alias et.al (2018), kesemuanya menyatakan bahwa sikap kerja berpengaruh positif dan signifikan terhadap kinerja. Dari hasil penelitian ini dapat dijelaskan bahwa sikap kerja pegawai di Dinas Pekerjaan Umum dan Penataan Ruang Kabupaten Labuhanbatu Selatan secara keseluruhan pada saat ini dalam kategori baik dan dapat meningkatkan kinerja pegawai.

\subsection{Pengaruh Lingkungan Kerja Terhadap Kinerja Pegawai di Dinas Pekerjaan}

\section{Umum dan Penataan Ruang} Kabupaten Labuhanbatu Selatan.

Berdasarkan pada hasil penelitian dapat dijelaskan bahwa lingkungan kerja berpengaruh positif dan signifikan terhadap kinerja pegawai di Dinas Pekerjaan Umum dan Penataan Ruang Kabupaten Labuhanbatu Selatan, hal ini didukung dengan hasil uji hipotesis yang menunjukkan bahwa nilai $t_{\text {hitung }}>t_{\text {tabel }}(5.650>$ 2.009) dan nilai signifikasi lebih kecil dari nilai $\alpha: 0.05$ yaitu $0.015<0.05$. Hasil penelitian ini sejalan dengan hasil penelitian terdahulu dari Wibawa (2014), dan Muzammil (2014); kesemuanya menyatakan bahwa lingkungan kerja berpengaruh positif dan signifikan terhadap kinerja. Dari hasil penelitian ini dapat dijelaskan bahwa lingkungan kerja pegawai di Dinas Pekerjaan Umum dan Penataan Ruang Kabupaten Labuhanbatu Selatan secara keseluruhan pada saat ini dalam kategori baik dan dapat meningkatkan kinerja pegawai. Lingkungan kerja dapat mempengaruhi hal tersebut dengan membentuk harapan pegawai tentang konsekuensi yang akan timbul dari berbagai tindakan. Para pegawai mengharapkan imbalan, kepuasan, prestasi atas dasar persepsi mereka terhadap lingkungan kerja.

\subsection{Pengaruh Motivasi Kerja Terhadap Kinerja Pegawai di Dinas Pekerjaan Umum dan Penataan Ruang Kabupaten Labuhanbatu Selatan.}

Berdasarkan pada hasil penelitian dapat dijelaskan bahwa motivasi kerja berpengaruh positif dan signifikan terhadap kinerja pegawai di Dinas Pekerjaan Umum dan Penataan Ruang Kabupaten Labuhanbatu Selatan, hal ini didukung dengan hasil uji hipotesis yang menunjukkan bahwa nilai $t_{\text {hitung }}>t_{\text {tabel }}(3.785>$ 2.009) dan nilai signifikasi lebih kecil dari nilai $\alpha: 0.05$ yaitu $0.000<0.05$. Hasil penelitian ini sejalan dengan hasil penelitian terdahulu dari Abdullah et.al. (2013), Ali et.al (2016), Milka et.al (2015), Noviansyah (2011) dan Saeed et.al (2016), kesemuanya menyatakan bahwa motivasi kerja berpengaruh positif dan 
signifikan terhadap kinerja. Dari hasil penelitian ini dapat dijelaskan bahwa motivasi kerja pegawai di Dinas Pekerjaan Umum dan Penataan Ruang Kabupaten Labuhanbatu Selatan secara keseluruhan pada saat ini dalam kategori baik dan dapat meningkatkan kinerja pegawai.

\section{Kesimpulan}

Berdasarkan pada pembahasan pada bab sebelumnya, maka dapat ditarik kesimpulan dari penelitian ini sebagai berikut :

1) Variabel sikap kerja secara partial berpengaruh positif dan signifikan terhadap kinerja pegawai di Dinas Pekerjaan Umum dan Penataan Ruang Kabupaten Labuhanbatu Selatan.

2) Variabel lingkungan kerja secara partial berpengaruh positif dan signifikan terhadap kinerja pegawai di Dinas Pekerjaan Umum dan Penataan Ruang Kabupaten Labuhanbatu Selatan.

3) Variabel motivasi kerja secara partial berpengaruh positif dan signifikan terhadap kinerja pegawai di Dinas Pekerjaan Umum dan Penataan Ruang Kabupaten Labuhanbatu Selatan.

4) Variabel sikap kerja, lingkungan kerja dan motivasi kerja secara simultan berpengaruh positif dan signifikan terhadap kinerja pegawai di Dinas Pekerjaan Umum dan Penataan Ruang Kabupaten Labuhanbatu Selatan.

\section{DAFTAR PUSTAKA}

Agus Marimin (2011), Pengaruh gaya kepemimpinan, motivasi kerja, dan budaya organisasi terhadap kinerja karyawan pada Bank Muamalat Indonesia Cabang Surakarta, Jurnal Manajemen dan Bisnis Sriwijaya Vol.3 No.16

Journal of Education and Social Science Vol. 3 No. 1; January 2016

Anoraga, Panji (2014). Psikologi Kerja, PT Rineka Cipta, Jakarta

Benardin, (2011), Manajemen Sumber Daya Manusia, PT. Preshelindo, Jakarta

Cascio, Wayne F.,( (2009) Managing Human Resources: Productivity, Quality of Work Life, Profits, edition, New York, McGraw Hill

Colquitt, J. A., LePine, J. A., and Wesson., (2009) Organizational Behavior: Improving Performance and Commitment in the Workplace, New York, McGraw Hill, pp. 37
Chres F.P Laoh, Bernhard Tewal, dan Sem G Oroh (2016), Pengaruh Pengetahuan, Keterampilan dan Sikap Kerja Terhadap Kinerja Pegawai (Studi Kasus Pada PT. National Nobu Bank Area Manado). Jurnal Berkala Ilmiah, Vol 16 No. 04

Cross, T.M dan Lynch. R.R. (2009). Peniliaian dan Evaluasi Kinerja: Konsep dan Praktik. Jakarta. Penerbit Ghalia Indonesia

David, Fred, R. (2014). Manajemen Stratejik: Konsep dan Kasus. Edisi ke 9. Jakarta. Salemba Empat

Dean, J. W., Brandes, P., dan Dharwadkar, R (2014). Organizational cynicism. The Academy of Management Review, 23(2).

Dessler, Gary. (2012). Manajemen Sumber Daya Manusia (Jilid I). Jakarta : Indeks.

Famella, Sri Wahyu Lelly Hana Setyanti, Ana Mufidah (2015), Pengaruh Keterampilan Kerja, Pengalaman Kerja, dan Sikap Kerja Terjadap Kinerja Karyawan Pada Perusahaan Rokok Gagak Hitam Kabupaten Bondowoso. Jurnal Universitas Jember.

Fonny Corryda Rahayu (2013), Pengaruh Sikap Kerja dan Komitmen Organisasi Terhadap Kinerja Karyawan Pada PT. Graha Agung Kencana Group Surabaya. Jurnal Universitas Pembangunan Nasional "Veteran" Jawa Timur

Hasibuan, Malayu S. P. (2014). Manajemen Sumber Daya Manusia. Edisi Revisi Jakarta: PT. Bumi Aksara.

Harlie, M. 2010. Pengaruh Disiplin Kerja, Motivasi dan Pengembangan Karier Terhadap Kinerja Pegawai Negeri Sipil Pada Pemerintah Kabupaten Tabalong di Tanjung Kalimantan Selatan. Jurnal Manajemen dan Akuntansi Vo11 (2): 10-23

Khumaedi, Erawati. 2016. Pengaruh Disiplin dan Motivasi Kerja terhadap Kinerja Pegawai pada Dinas Sentra Operasi Terminal PT. Angkasa Pura II. Jurnal Manajemen dan Bisnis Vol. 2, No. 1, Maret

Mangkunegara, Anwar, Prabu. (2009). Evaluasi Kinerja SDM, Cetakan 4, Bandung : Refika Aditama

Mangkuprawira, Sjafri. (2014). Manajemen Sumber Daya Manusia Strategik. Cetakan ketiga, Penerbit Ghalia Indonesia

Muzammil, Aidil (2014). Analisis Lingkungan Kerja dan Beban Kerja Terhadap Kinerja Karyawan. Jurnal Ilmu Ekonomi dan Bisnis

Nisyak, Ila Rohmatun., dan Trijonowati. (2016), Pengaruh Gaya Kepemimpinan, Motivasi dan Disiplin Kerja Terhadap 
Kinerja Karyawan. Jurnal Ilmu dan Riset Manajemen : Volume 5, Nomor 4, April 2016. STIESIA

Nair, P.P dan Ganesh, S.S. (2016). Effects of Motivation, Stress and Compensation Benefits on Employee Performance in IT Progessionals. International Journal of Advanced Research (2016), Volume 4, Issue 1, 1349- 1357

Noviansyah dan Zunaidah (2011). Pengaruh Karakteristik Pekerjaan Dan Motivasi Kerja Terhadap Kinerja Karyawan PT. Perkebunan Minanga Ogan Baturaja. Jurnal Manajemen dan Bisnis Sriwijaya Vol.9 No.18.

Novyanti, Joyce Sagita. 2015. Pengaruh Motivasi Kerja, Lingkungan Kerja dan Disiplin Kerja terhadap Kinerja Pegawai pada BAPPEDA Provinsi Sulawesi Tengah. Tesis. Palu: Universitas Tadakulo

Rd. Kresna Yudi Kusumah, Sri Suwarsi, Dudung Abdurrahman (2017), Pengaruh Kompetensi Dan Sikap Kerja Terhadap Kinerja Karyawan Di Hashi Ramen Bar Dan Resto Cimahi, SPeSIA, Prosiding Manajemen, Vol. 3, No.2

Rivai, Veithzal dan Sagala, Ella Jauvani. (2009). Manajemen Sumber Daya Manusia Untuk Perusahaan : Dari Teori ke Praktek. Jakarta : PT. Rajagrafindo Persada

Robbins S.P dan Judge,T.A. (2012). Perilaku Organisasi. Buku 1 Edisi 12. Terjemahan Diana Angelica. Penerbit Salemba Empat. Jakarta.

Saeed, S., dan Syah, F.M (2016). Impact of Performance Appraisal on Employee Motivation in Islamic Banking. Arabian Journal of Business and Management Review (OMAN Chapter). Vol. 5, No.7; February 2016

Samsudin, Sadili. (2009). Manajemen Sumber Daya Manusia. Bandung: CV. Pustaka Setia.

Sedarmayanti. (2014). Good Governance (Kepemerintahan Yang Baik), Bandung : Mandar Maju

Sekaran, Uma dan Roger Bougie, (2017), Metode Penelitian untuk Bisnis: Pendekatan Pengembangan-Keahlian, Edisi 6, Buku 1, Cetakan Kedua, Salemba Empat, Jakarta Selatan 12610.

Siagian, Sondang. (2014). Manajemen Sumber Daya Manusia (cetakan 15). Jakarta: Bumi Aksara

Sidanti, Heni. 2015. Pengaruh Lingkungan Kerja, disiplin kerja dan motivasi Kerja terhadap Kinerja Pegawai Negeri Sipil di
Sekretariat DPRD Kabupaten Madiun. Jurnal Ilmiah Ilmu-Ilmu Ekonomi dan Bisnis (JIBEKA). Vol.9, No 1

Sink, R dan Tuttle, J.K. (2009). Evaluasi Kinerja. Jakarta: Indeks Kelompok Gramedia.

Sugiyono. (2016). Metode Penelitian Kuantitatif dan Kualitatif dan $\mathrm{R}$ dan D. Bandung : Alfabeta

Thoha, Miftah. (2011). Birokrasi Indonesia Dalam Era Globalsasi, Pusdiklat Pegawai Depdiknas, Sawangan, Bogor

Trisno, I \& Suwarti, T. 2004. Analisis Pengaruh Kompensasi dan Lingkungan Kerja terhadap Kinerja Aparat Pemerintah (Studi Kasus Pada Dinas Perindustrian dan Peradagangan Kabupaten Pati). Jurnal Ilmiah Telaah Manajemen, Vol.1, No 1

Wibawa, I. G. K. Arya. (2014). Pengaruh Kompensasi Dan Lingkungan Kerja Terhadap Kinerja Karyawan. Jurnal Ekonomi dan Bisnis.Wignosubroto

Yazid, Musnadi dan Chan, (2013). Pengaruh Gaya Kepemimpinan, Budaya Organisasi dan Motivasi Kerja Terhadap Prestasi Kerja Pegawai Administrasi serta Dampaknya pada Kinerja Politeknik Negeri Lhoseumawe, Aceh. Jurnal Manajemen Pascasarjana Universitas Syiah Kuala. ISSN 2302-0199. pp. 78- 87 